Artikel Penelitian

\title{
PERBANDINGAN PROGNOSIS SUBTIPE MOLEKULER KANKER PAYUDARA ANTARA PASIEN KANKER PAYUDARA WANITA USIA MUDA DAN TUA DI RSUP DR. M. DJAMIL PADANG
}

\author{
Irwan $^{1}$, Azamris ${ }^{1}$, Hafni Bachtiar ${ }^{2}$
}

\begin{abstract}
Abstrak
Penelitian sebelumnya menunjukkan bahwa subtipe molekuler kanker payudara memiliki perbedaan distribusi dan efek prognostik antara usia muda dan tua, sedangkan data lokal maupun nasional tidak ada penulis temukan. Metode : Penelitian komparatif dengan metode cross sectional. Dilakukan bulan Januari - April 2015, sampel 96 penderita kanker payudara wanita usia $\leq 40$ tahun dan $>40$ tahun yang tercatat di rekam medis dan registrasi kanker payudara dari tahun 2012 - 2014. Hasil : Kejadian kanker payudara wanita usia muda di RSUP dr. M. Djamil Padang selama 3 tahun (2012-2014) yaitu 27,1\% dan usia tua $72,9 \%$. Analisa bivariat tidak menunjukkan hubungan yang signifikan antara berbagai karakteristik tumor dengan kejadian residif dan meninggal pada usia muda. Sedangkan pada usia tua, terdapat hubungan yang signifikan antara ukuran tumor dan metastasis terhadap kejadian residif dan meninggal. Kesimpulan : Ada perbedaan karakteristik dan gambaran subtipe molekuler kanker payudara antara usia muda dan tua, usia muda tumor cenderung berukuran besar, kelenjar getah bening positif, adanya invasi limfovaskuler, grade tumor tinggi, indeks proliferasi Ki67 tinggi serta reseptor hormon negatif. Terdapat kecenderungan perbedaan prognosis kanker payudara wanita antara usia muda dan tua berdasarkan subtipe molekuler namun tidak bermakna secara statistik.
\end{abstract}

Kata kunci : Usia, subtipe molekuler kanker payudara, prognosis

\begin{abstract}
Previous study showed that molecular subtypes of breast cancer have different distribution and prognostic effect between the young and adult, whereas it cannot found in the local and national data. Method : Comparative research with cross sectional design. Held in January-April 2015, Ninety six samples of breast cancer women with age $\leq 40$ years old and $>40$ years old that has been recorded in medical records and breast cancer registration from year 2012-2014. Result : Breast cancer that happened to young women at General Hospital dr. M. Djamil Padang for 3 years (2012-2014) are 27,1\% and the adult are 72,9\%. In bivariat analysis, there are not relationship between characteristics of tumor with recurrent and death while in the adult women breast cancer, tumor size and metastases have relation with recurrent and death that are significant statistically. Conclusion : There are different characteristics and description of breast cancer molecular subtype between young and adult women, young ages are tend to have big tumor, lymph node positive, lymphovascular invasion, high grade tumor, proliferation index Ki67 high and negative hormone receptor. There are differences tendency of prognosis women breast cancer between the young and adult based on molecular subtype but statistically, the relationship is not significant.
\end{abstract}

Keyword: Age, breast cancer molecular subtype, prognosis

Afiliasi Penulis: 1. Bagian IImu Bedah Fakultas Kedokteran Universitas Andalas / RSUP dr. M. Djamil Padang, 2. Bagian IImu Kesehatan Masyarakat Fakultas Kedokteran Universitas Andalas. Korespondensi : Irwan, email : irwanabdulrachman@gmail.com, HP: 085365167018 


\section{PENDAHULUAN}

Kanker payudara merupakan penyakit heterogen dengan beragam profil biologis serta prognosis klinis. ${ }^{1}$ Kanker payudara sebagian besar mengenai wanita usia tua, namun panduan khusus mengenai terapi yang berbasis bukti pada kelompok usia ini masih kurang. Sebaliknya pada populasi wanita kanker payudara usia muda, keputusan mengenai tatalaksana kanker payudara telah didasarkan pada faktor prognostik dan prediktif pasien serta karakteristik tumor. ${ }^{2}$ The European Society of Breast Cancer Specialist mendefinisikan wanita usia muda (young women) adalah wanita yang berusia di bawah 40 tahun. $^{3}$

Acuan prognosis untuk masingmasing pasien berdasarkan analisa penanda biologis tumor primer yang mencakup reseptor estrogen (ER), reseptor progesteron (PR), Human Epidermal Growth Factor receptor 2 (HER2) dan Ki67 bersamaan dengan usia, status menopausal, ukuran tumor, grading histologi serta keterlibatan kelenjar getah bening. St Gallen International Breast Cancer Conference memberikan definisi tentang subtipe intrinsik kanker payudara yaitu luminal $A$ (ER+, PR+, HER2- dan Ki67 rendah), luminal $\mathrm{B}(\mathrm{ER}+, \mathrm{PR}+, \mathrm{HER} 2-, \mathrm{Ki} 67$ tinggi), HER2-overexpression (ER-, PRHER2+) dan basal like atau triple negative (ER-, PR-, HER2-). ${ }^{1,4,5}$

Usia merupakan faktor penting untuk resiko rekurensi tanpa bergantung pada faktor lainnya (independent risk factor). ${ }^{6,7}$ Sekitar 25\% kanker payudara terjadi sebelum usia menopause. ${ }^{8}$ Ketika usia pasien dan status menopausal dianalisa secara bersamaan, usia menjadi faktor penentu utama dalam peningkatan reseptor estrogen. Jadi wanita usia tua memiliki reseptor estrogen yang lebih tinggi dibandingkan wanita usia muda. Namun jika usia yang sama dibandingkan, wanita dengan status premenopausal memiliki konsentrasi reseptor progesteron lebih tinggi daripada wanita postmenopausal. ${ }^{9}$

Terdapat hubungan antara usia dengan karakteristik biologis tumor yang baik (favorable). Dibandingkan dengan usia muda, pasien kanker payudara usia tua memiliki lebih banyak tumor yang diploid, fraksi S-phase yang rendah, p53 normal, reseptor epidermal growth factor dan c-erbB2 yang negatif atau rendah. ${ }^{10}$ Kanker payudara pada wanita usia di bawah 40 tahun cenderung berukuran lebih besar (dengan median tumor $2 \mathrm{~cm}$ pada usia muda dan $1,5 \mathrm{~cm}$ pada usia tua), stadiumnya lebih lanjut pada saat diagnosis (lebih berkemungkinan dengan kelenjar getah bening positif) dan lebih agresif (kecil kemungkinan untuk berdiferensiasi baik), ekspresi estrogen/progesterone receptor (ER/PR) yang rendah dan ekspresi human epidermal growth factor receptor 2 (HER2) yang tinggi serta proliferasi marker Ki67. ${ }^{11,12,13,14,15}$

Tumor dengan reseptor hormon positif memiliki luaran yang lebih baik, dimana tumor dengan luminal $A$ bersifat lebih lambat progresifitasnya dibandingkan dengan tumor luminal B, sedangkan tumor dengan reseptor hormon negatif memiliki perjalanan alamiah yang agresif dan keluaran yang jelek. $^{2}$ Meskipun dengan terapi yang optimal, beberapa studi klinis menunjukkan bahwa pasien kanker payudara usia muda memiliki luaran yang jelek dibanding pasien yang 
mengalami kanker payudara di usia tua. ${ }^{16}$

Jadi penanda biologis imunohistokimia ini dapat menunjukkan perbedaan efek prognostik dan prediktif antara penderita kanker payudara usia tua dengan usia muda. Tetapi sedikit sekali diketahui mengenai implikasi penanda biologis ini terhadap luaran penderita kanker payudara usia tua. ${ }^{2}$

Distribusi dan efek prognostik subtipe molekuler tertentu dari populasi kanker payudara usia tua dibandingkan dengan usia muda masih belum diketahui. ${ }^{2}$ Penelitian di Belanda oleh Esther, dkk 2013 telah menunjukkan bahwa subtipe molekuler kanker payudara memiliki perbedaan distribusi dan efek prognostik antara penderita kanker payudara usia tua dibandingkan dengan usia muda. ${ }^{2}$ Sedangkan data mengenai perbandingan distribusi dan prognosis subtipe molekuler kanker payudara antara penderita kanker payudara usia muda dan tua baik lokal maupun nasional tidak ada penulis temukan.

Hal inilah yang membuat penulis ingin meneliti bagaimana perbandingan prognosis subtipe molekuler kanker payudara antara penderita kanker payudara usia muda dan tua di RSUP dr. M. Djamil Padang.

\section{METODE}

Desain yang digunakan dalam penelitian ini bersifat komparatif, dengan metode penelitian cross sectional tentang perbandingan prognosis subtipe molekuler kanker payudara antara penderita kanker payudara usia muda dan tua. Penelitian dilakukan pada bulan Januari - April 2015 di bagian bedah
Fakultas Kedokteran Universitas Andalas/RSUP dr. M. Djamil Padang. Populasi dalam penelitian ini adalah seluruh penderita kanker payudara yang tercatat dalam rekam medis dan registrasi kanker payudara divisi Onkologi bagian Bedah RSUP dr. M. Djamil Padang. Sampel yang diambil dalam penelitian ini adalah penderita kanker payudara yang sudah didiagnosis dan mendapatkan terapi menurut protokol dan tercatat pada Rekam Medis dan Registrasi Kanker Payudara Divisi Onkologi di Bagian Bedah RSUP dr. M. Djamil Padang pada tahun 2012 - 2014 dengan menggunakan teknik simple random sampling. Kriteria inklusi yaitu Penderita kanker payudara wanita usia muda ( $\leq 40$ tahun) dan tua ( $>40$ tahun) yang telah dilakukan pemeriksaan histopatologi dan imunohistokimia. Jika penderita kanker payudara disertai kanker pada organ lainnya yang bukan metastasis dari kanker payudara, meninggal dalam periode tiga tahun oleh karena sebab lain dan data rekam medis yang tidak dapat ditelusuri akan dimasukkan ke dalam kriteria ekslusi. Variabel bebas adalah subtipe molekuler kanker payudara, variabel tergantung adalah prognosis kanker payudara dan variabel pendahulu adalah usia.

\section{HASIL DAN PEMBAHASAN}

Dari data rekam medis dan registrasi kanker payudara didapatkan 96 penderita kanker payudara yang berobat ke RSUP dr. M. Djamil Padang tahun 2012- 2015. Kesulitan penelitian ini adalah kurangnya evaluasi terhadap grade tumor dan status invasi limfovaskuler yang dibacakan oleh bagian Patologi Anatomi, dari 96 
penderita hanya 59 penderita yang memiliki grade tumor sedangkan status invasi limfovaskuler hanya 32 penderita. Terdapat 27 kasus kanker payudara yang residif dan 15 penderita kanker payudara yang meninggal, namun hanya 12 penderita yang meninggal karena kanker payudara.

Data diolah dengan menggunakan program komputer. Analisis data dilakukan secara deskriptif dan mencari untuk mencari hubungan antar 2 variabel digunakan uji Chi - kuadrat dengan derajat kepercayaan 95\%.

\section{Tabel 1. Karakteristik Sampel}

\begin{tabular}{|c|c|c|}
\hline Karakteristik & $\mathbf{F}$ & $\%$ \\
\hline \multicolumn{3}{|l|}{ Usia } \\
\hline$\leq 40$ tahun & 26 & 27,1 \\
\hline$>40$ tahun & 70 & 72,9 \\
\hline \multicolumn{3}{|l|}{ Jenis histopatologi } \\
\hline Invasif ductal ca & 76 & 79,2 \\
\hline Invasif lobular ca & 20 & 20,8 \\
\hline \multicolumn{3}{|l|}{ Grade tumor } \\
\hline Grade I & 6 & 10,2 \\
\hline Grade II & 42 & 71,2 \\
\hline Grade III & 11 & 18,6 \\
\hline \multicolumn{3}{|l|}{ Invasi limfovaskuler } \\
\hline Tidak ada invasi & 17 & 53,1 \\
\hline Ada invasi & 15 & 46,9 \\
\hline \multicolumn{3}{|l|}{ Ukuran tumor } \\
\hline $\mathrm{T} 1$ & 5 & 5,2 \\
\hline T2 & 36 & 37,5 \\
\hline T3 & 16 & 16,7 \\
\hline $\mathrm{T} 4$ & 39 & 40,6 \\
\hline \multicolumn{3}{|l|}{ Kelenjar getah bening } \\
\hline Negatif & 27 & 28,1 \\
\hline Positif & 69 & 71,9 \\
\hline \multicolumn{3}{|l|}{ Metastasis } \\
\hline Mo & 89 & 92,7 \\
\hline M1 & 7 & 7,3 \\
\hline \multicolumn{3}{|l|}{ Subtipe molekuler } \\
\hline Luminal $\mathrm{A}$ & 11 & 11,5 \\
\hline Luminal B & 38 & 39,6 \\
\hline HER2overexpression & 25 & 26,0 \\
\hline Triple negative & 22 & 22,9 \\
\hline \multicolumn{3}{|l|}{ Prognosis } \\
\hline Residif & 27 & 28,1 \\
\hline Meninggal & 15 & 15,6 \\
\hline
\end{tabular}

\section{Tabel 2. Hubungan karakteristik tumor dengan kejadian residif ber- dasarkan usia}

\begin{tabular}{|c|c|c|c|c|c|c|c|c|c|}
\hline \multirow{2}{*}{ Karakteristik } & \multicolumn{3}{|c|}{$\leq 40$ tahun } & \multicolumn{3}{|c|}{$>40$ tahun } & \multicolumn{3}{|c|}{ Total } \\
\hline & $f$ & $\%$ & $p$ & f & $\%$ & $p$ & $f$ & $\%$ & p \\
\hline \multicolumn{10}{|l|}{ Histopatologi } \\
\hline Ductal & 8 & 38,1 & & 14 & 25,5 & & 22 & 28,9 & \\
\hline Lobular & 2 & 40,0 & 1,00 & 3 & 20,0 & 1,00 & 5 & 25,0 & 0,444 \\
\hline \multicolumn{10}{|l|}{ Grade } \\
\hline 1 & 0 & 0 & & 0 & 0,0 & & 0 & 0,0 & \\
\hline$\|$ & 6 & 50,0 & 1,00 & 7 & 23,3 & 0,194 & 13 & 31,0 & 0,226 \\
\hline III & 2 & 100,0 & & 0 & 0,0 & & 2 & 18,2 & \\
\hline \multicolumn{10}{|c|}{ Invasi Limfovaskuler } \\
\hline Tidak ada invasi & & . & & 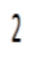 & 11,8 & & 2 & 11,8 & \\
\hline Ada invasi & 3 & 50,0 & & 2 & 22,2 & 0,391 & 5 & 33,3 & 209 \\
\hline
\end{tabular}

\begin{tabular}{|c|c|c|c|c|c|c|c|c|c|}
\hline \multirow{2}{*}{ Karakteristik } & \multicolumn{3}{|c|}{$\leq 40$ tahun } & \multicolumn{3}{|c|}{$>40$ tahun } & \multicolumn{3}{|c|}{ Total } \\
\hline & $f$ & $\%$ & $p$ & $f$ & $\%$ & $p$ & $f$ & $\%$ & $p$ \\
\hline \multicolumn{10}{|l|}{ Ukuran Tumor } \\
\hline $\mathrm{T} 1$ & - & . & & 0 & 0,0 & \multirow{4}{*}{0,449} & 0 & 0,0 & \multirow{4}{*}{0,198} \\
\hline $\mathrm{T} 2$ & 1 & 14,3 & & 7 & 24,1 & & 8 & 22,2 & \\
\hline Т3 & 1 & 100,0 & & 3 & 20,0 & & 4 & 25,5 & \\
\hline T4 & 8 & 44,4 & & 7 & 33,3 & & 15 & 38,5 & \\
\hline \multicolumn{10}{|l|}{$\mathrm{N}$} \\
\hline Negatif & 1 & 25,0 & \multirow{2}{*}{1,00} & 4 & 17,4 & \multirow{2}{*}{0,519} & 5 & 18,5 & \multirow{2}{*}{0,290} \\
\hline Positif & 9 & 40,9 & & 13 & 27,7 & & 22 & 31,9 & \\
\hline \multicolumn{10}{|c|}{ Subtipe Molekuler } \\
\hline Luminal A & 0 & 0 & \multirow{4}{*}{1,00} & 0 & 0,0 & & 0 & 0,0 & \multirow{4}{*}{0,226} \\
\hline Luminal B & 6 & 50,0 & & 7 & 23,3 & \multirow{3}{*}{0,194} & 13 & 31,0 & \\
\hline $\begin{array}{l}\text { HER2 } \\
\text { overexpression }\end{array}$ & 2 & 100,0 & & 0 & 0,0 & & 2 & 18,2 & \\
\hline Triple negative & 4 & 44,4 & & 1 & 7,7 & & 5 & 22,7 & \\
\hline
\end{tabular}

Banyak faktor yang mempengaruhi prognostik kanker payudara dan usia merupakan faktor penting untuk resiko rekurensi tanpa bergantung pada faktor lainnya (independent risk factor). ${ }^{6,7,17,18,19}$ Terdapat hubungan antara usia dengan karakteristik biologis tumor. ${ }^{10}$

Subtipe histologi merupakan salah satu faktor prognostik kanker payudara. ${ }^{18}$ Jenis histopatologi kanker payudara terbanyak adalah karsinoma duktal invasif (Samina Khokher, et al 
dengan persentase 91\% dan American Cancer Society dengan perbandingan 10:1 terhadap karsinoma lobular invasif). Terdapat perbedaan karakteristik tumor antara karsinoma duktal invasif dan karsinoma lobular invasif. Karsinoma lobular invasif terjadi pada usia lebih tua, ukuran tumor lebih besar, reseptor hormon yang positif, HER2 dan p53 yang negatif, kurang sering menginvasi pembuluh darah jika dibandingkan dengan karsinoma duktal invasif tetapi lebih sering multifokal, multisentrik dan bilateral, berkaitan dengan meningkatnya resiko terjadinya kanker payudara kontralateral, grade histology yang rendah, lebih sering bermetastasis pada lokasi yang tidak biasa seperti saluran cerna dan meningen. Secara khusus, karsinoma lobular invasif menunjukkan ciri yang berkaitan dengan prognosis yang baik dibandingkan karsinoma duktal invasif. ${ }^{22,23}$

Pada penelitian ini karsinoma duktal invasif merupakan jenis yang paling banyak yaitu 76 penderita $(79,2 \%)$. Dari 20 penderita karsinoma lobular invasif, sebagian besar terjadi pada usia tua ( $>40$ tahun) yaitu 15 penderita. Namun persentase kejadian residif dan meninggal lebih besar pada penderita kanker payudara usia muda $(38,5 \%$ dan $16,7 \%)$ dengan jenis histopatologi yang sama yaitu karsinoma lobular invasif (40\% dan 20\%).

Jika dikaitkan dengan karakteristik tumor lainnya, karsinoma lobular invasif pada usia muda dalam penelitian ini memiliki tumor dengan stadium T4 dan kelenjar getah bening yang positif. Sebagian besar dengan ER (-), PR (-) dan HER2 (-). Satu penderita dengan metastasis paru. Jadi pada penelitian ini tampak bahwa usia muda lebih mempengaruhi karakteristik tumor dibandingkan jenis histopatologi tumor itu sendiri sehingga meskipun karsinoma lobular invasif yang memiliki prognosis lebih baik, akan menjadi buruk jika terjadi pada usia muda.

\section{Tabel 3. Hubungan karakteristik tumor dengan kejadian meninggal berdasarkan usia}

\begin{tabular}{|c|c|c|c|c|c|c|c|c|c|}
\hline \multirow{2}{*}{ Karakteristik } & \multicolumn{3}{|c|}{$\leq 40$ tahun } & \multicolumn{3}{|c|}{$>40$ tahun } & \multicolumn{3}{|c|}{ Total } \\
\hline & $f$ & $\%$ & $p$ & f & $\%$ & $p$ & $f$ & $\%$ & p \\
\hline \multicolumn{10}{|l|}{ Histopatologi } \\
\hline Ductal & 3 & 15,8 & \multirow{2}{*}{1,00} & 6 & 11,1 & \multirow{2}{*}{1,00} & 9 & 12,3 & \multirow{2}{*}{0,717} \\
\hline Lobular & 1 & 20,0 & & 2 & 13,3 & & 3 & 15,0 & \\
\hline \multicolumn{10}{|l|}{ Grade } \\
\hline | & 0 & 0 & \multirow{3}{*}{0,464} & 0 & 0,0 & \multirow{3}{*}{0,795} & 0 & 0,0 & \multirow{3}{*}{0,616} \\
\hline$\|$ & 2 & 18,2 & & 4 & 13,3 & & 6 & 14,6 & \\
\hline$\|$ & 1 & 50,0 & & 1 & 11,1 & & 2 & 18,2 & \\
\hline \multicolumn{10}{|c|}{ Invasi limfovaskuler } \\
\hline Tidakada invasi & - & $\cdot$ & & . & - & & 0 & 0,0 & \multirow{2}{*}{0,092} \\
\hline Adainvasi & 3 & 50,0 & & - & . & & 3 & 20,0 & \\
\hline \multirow{2}{*}{ Karakteristik } & \multicolumn{3}{|c|}{$\leq 40$ tahun } & \multicolumn{3}{|c|}{$>40$ tahun } & \multicolumn{3}{|c|}{ Total } \\
\hline & $f$ & $\%$ & $p$ & $f$ & $\%$ & $p$ & $f$ & $\%$ & $p$ \\
\hline \multicolumn{10}{|l|}{ Ukuran Tumor } \\
\hline $\mathrm{T} 1$ & - & - & \multirow{4}{*}{0,317} & 0 & 0,0 & \multirow{4}{*}{0,030} & 0 & 0,0 & \multirow{4}{*}{0,011} \\
\hline T2 & 7 & 100,0 & & 2 & 7,1 & & 2 & 5,7 & \\
\hline Т3 & 1 & 100,0 & & 0 & 0,0 & & 0 & 0,0 & \\
\hline T4 & 12 & 75,0 & & 6 & 28,6 & & 10 & 27,0 & \\
\hline \multicolumn{10}{|l|}{ N } \\
\hline Negatif & 0 & 0,0 & \multirow{2}{*}{1,00} & 1 & 4,5 & \multirow{2}{*}{0,421} & 1 & 3,8 & \multirow{2}{*}{0,168} \\
\hline Positif & 4 & 20,0 & & 7 & 14,9 & & 11 & 16,4 & \\
\hline \multicolumn{10}{|l|}{ M } \\
\hline Negatif & 3 & 13,6 & \multirow{2}{*}{0,312} & 5 & 7,8 & \multirow{2}{*}{0,010} & 8 & 9,3 & 0,005 \\
\hline Positif & 1 & 50,0 & & 3 & 60,0 & & 4 & 57,1 & 0,005 \\
\hline Subtipe Molekule & & & & & & & & & \\
\hline Luminal A & 1 & 33,3 & & 1 & 12,5 & & 2 & 18,2 & \\
\hline Luminal B & 2 & 33,3 & & 9 & 28,1 & & 11 & 28,9 & \\
\hline $\begin{array}{l}\text { HER2 } \\
\text { overexpression }\end{array}$ & 3 & 37,5 & 0,230 & 6 & 35,3 & 0,973 & 9 & 36,0 & 0,652 \\
\hline Triple Negative & 4 & 44,4 & & 1 & 7,7 & & 5 & 22,7 & \\
\hline
\end{tabular}

Grade histologi tumor dinilai berdasarkan derajat diferensiasi dari jaringan tumor. ${ }^{24}$ Tumor dengan grade tinggi memiliki gambaran abnormal dan cenderung menjadi agresif, rekurensi dan metastasis. Penderita kanker 
payudara dengan tumor yang high grade termasuk dalam kelompok high risk dan terdapat indikasi untuk kemoterapi adjuvant. $^{25}$ Terdapat hubungan terbalik antara grade diferensiasi tumor dengan pathomorphological response (PMR) grade pada pasien kanker payudara yang diberikan kemoterapi neoadjuvant, dimana tumor yang berdiferensiasi baik rata-rata memiliki respon yang jelek. ${ }^{26}$

Pada penelitian ini didapatkan kejadian residif dan meninggal lebih tinggi pada tumor dengan grade II dan III. Berdasarkan usia, penderita kanker payudara usia muda memiliki prognosis yang lebih jelek dibandingkan usia tua karena sebagian besar tumor memiliki grade III. Sedangkan pada usia tua kejadian residif dan meninggal, sebagian besar terdapat pada tumor dengan grade II. Pada umumnya tumor - tumor ini berukuran lebih besar ( $\geq \mathrm{T} 2$ ), memiliki kelenjar getah bening yang positif pada saat diagnosis, reseptor hormon bervariasi baik positif maupun negatif namun sebagian besar tumor memiliki indeks Ki67 tinggi $\geq 14 \%$. Hal ini sesuai dengan sifat - sifat tumor dengan grade histologi yang tinggi, dimana semakin tinggi grade tumor akan semakin agresif dan cepat proliferasinya yang ditandai dengan indeks Ki67 tinggi, ukuran yang besar, adanya invasi ke jaringan lain seperti kelenjar getah bening meskipun belum terdapat metastasis jauh saat diagnosis. Sebagian besar penderita mendapatkan terapi adjuvant, namun terjadi residif baik lokoregional maupun jauh serta meninggal dalam waktu $\leq 3$ tahun setelah diagnosis. Hal ini kemungkinan disebabkan karena telah adanya proses rekurensi ketika dalam terapi dan kriteria lainnya yang membuat penderita berada dalam kelompok resiko tinggi yaitu usia muda dan kelenjar getah bening yang positif.

Invasi limfovaskuler merupakan sebuah langkah penting dalam proses kompleks untuk terjadinya metastasis dari suatu tumor dan sebuah kriteria yang sangat penting untuk terapi selanjutnya. $^{27}$ Invasi limfovaskuler merupakan sebuah faktor prognostik jelek yang tidak tergantung (independent) pada penderita dengan kanker payudara invasif. ${ }^{28}$ Young Ju Song, dkk mendapatkan persentase OS dan DFS 5 tahun lebih rendah pada penderita dengan invasi limfovaskuler dibandingkan dengan yang tidak. ${ }^{28}$ Pada penelitian ini, penderita dengan invasi limfovaskuler memiliki prognosis yang jelek dengan persentase residif dan meninggal lebih tinggi (33,3\% dan 20\%). Hasil uji statistik menunjukkan tidak ada hubungan antara invasi limfovaskuler dengan residif dan meninggal dunia ( $p=$ $0,209$ dan $p=0,092)$. Tidak ada data mengenai kejadian residif pada penderita usia muda tanpa invasi limfovaskuler dan kematian pada penderita usia tua dengan atau tanpa invasi limfovaskuler sehingga sulit untuk membandingkan prognosis dengan adanya invasi limfovaskuler pada kedua kelompok usia tersebut. Hal ini karena dari 96 penderita hanya 32 orang yang memiliki status invasi limfovaskuler.

Semua pasien dengan invasi limfovaskuler yang residif dan meninggal dalam penelitian ini memiliki jenis histopatologi karsinoma duktal invasif, hal ini sesuai dengan kepustakaan dimana jenis ini lebih sering menginvasi jaringan limfovaskuler dibandingkan karsinoma lobular invasif. Penderita usia muda memiliki prognosis lebih jelek. Semua penderita muda yang residif, 
meninggal setelah terapi sedangkan pada penderita usia tua yang residif tidak ada yang meninggal. Jika dilihat dari karakteristik tumor, alasan yang dapat dikemukan mengenai jeleknya prognosis pada usia muda adalah ukuran tumor yang besar, adanya kelenjar getah bening yang positif, grade tumor yang tinggi, reseptor hormon yang negatif serta indeks proliferasi Ki67 yang tinggi. Jadi terdapat akumulasi beberapa faktor prognostik yang jelek pada penderita kanker payudara usia muda. Perbedaan dengan penderita kanker payudara usia tua, prognosis yang lebih baik karena adanya reseptor hormon estrogen dan progesteron yang positif dan nilai Ki67 yang rendah.

Ukuran tumor merupakan salah satu faktor prognostik kanker payudara. ${ }^{17}$ Ukuran tumor berkorelasi dengan terdapatnya dan jumlah kelenjar getah bening aksila yang terlibat, dan juga merupakan sebuah faktor prognostik yang tidak tergantung (independent), dengan peningkatan rata - rata rekurensi jauh seiring bertambah besarnya ukuran tumor. ${ }^{29}$ Letalitas kanker payudara meningkat dengan ukuran tumor dan adanya kelenjar getah bening regional. ${ }^{30}$ Pada penelitian ini didapatkan kejadian residif dan meninggal meningkat seiring dengan meningkatnya ukuran tumor $(38,5 \%$ dan $27 \%)$. Pada usia muda, tumor cenderung berukuran lebih besar dan kejadian residifnya lebih tinggi dibandingkan usia tua. Persentase tumor dengan T4 pada usia muda yang mengalami residif $(44,4 \%)$ sedangkan pada usia tua (33,3\%). Pada kedua usia, sebagian besar tumor dengan T4 ini memiliki kelenjar getah bening yang positif. Penderita kanker payudara usia muda lebih banyak yang meninggal dengan persentase $(16,7 \%)$ disbandingkan usia tua $(11,6 \%)$, namun tumor dengan T4 lebih banyak yang meninggal pada usia tua $(28,6 \%)$. Hal ini kemungkinan disebabkan karena sebagian besar penderita telah memiliki metastasis jauh pada saat diagnosis. Hubungan ini bermakna secara statistik baik ukuran tumor dengan kejadian meninggal pada usia tua $(p=0,03)$ maupun metastasis dengan kejadian meninggal pada usia tua $(p=0,01)$. Hal ini dapat diterangkan bahwa sebagian besar penderita usia tua yang meninggal dengan tumor T4 memiliki metastasis.

Reseptor hormon, ekspresi HER2 dan Ki67 merupakan salah satu faktor prognostik kanker payudara. ${ }^{18}$ Tumor dengan reseptor hormon positif memiliki luaran (outcome) yang lebih baik dibandingkan tumor dengan reseptor hormon negatif. $^{2}$ Sedangkan Ki67 menggambarkan proliferasi sel tumor dan memberikan informasi tambahan dan prediksi independen terhadap respon kemoterapi dan prognosis pada kelompok pasien kanker payudara yang mendapatkan terapi neoadjuvant. ${ }^{20,21}$ Kanker payudara pada wanita usia muda ( $\leq 40$ tahun) cenderung memiliki ekspresi reseptor estrogen/progesteron yang rendah dan ekspresi HER2 yang tinggi serta proliferasi penanda Ki67. ${ }^{11,12,13,14,15}$ Hasil penelitian ini sesuai dengan kepustakaan tersebut dimana penderita kanker payudara wanita usia muda ( $\leq 40$ tahun) memiliki prognosis yang lebih jelek dari usia tua ( $>40$ tahun) dengan persentase residif dan meninggal yang lebih tinggi $(38,5 \%$ vs $24,3 \%$ dan $16,7 \%$ vs $11,6 \%$ ). Prognosis yang jelek pada usia muda ini juga sesuai dengan jenis subtipe molekuler yang didapatkan yaitu triple negative 
(ER/PR-, HER2 -). Pada usia tua (> 40 tahun) kejadian residif lebih banyak pada subtipe HER2 overexpression dan persentase yang meninggal lebih tinggi pada subtipe Luminal B. Namun secara statistik, hubungan antara subtipe molekuler dengan prognosis kanker payudara berdasarkan usia tidak signifikan. Kejadian residif dan meninggal pada penderita usia muda, lebih tinggi pada subtipe molekuler apapun dibandingkan usia tua, hal ini kemungkinan besar karena adanya akumulasi berbagai faktor prognosis yang jelek pada kelompok usia tersebut yaitu ukuran tumor yang relatif besar, kelenjar getah bening yang positif, adanya invasi limfovaskuler, grade tumor yang tinggi, indeks proliferasi Ki67 yang tinggi. Jadi usia muda berhubungan dengan prognosis kanker payudara yang jelek.

Seperti kanker lainnya, kanker payudara dianggap sebagai bagian dari akumulasi perubahan genetik yang multipel sehingga terjadi ekspresi onkogen yang berlebihan dan kehilangan penekan tumor (tumor suppressor). Perubahan metilasi DNA pada akhirnya akan menyebabkan ketidakstabilan karakteristik genetik pada kanker melalui beberapa cara. ${ }^{31}$ Data mengenai metilasi telah dihubungkan dengan parameter klinikopatologi untuk menjelaskan peranan metilasi pada karsinogenesis kanker payudara. Laporan dari Widschwendter, dkk menunjukkan adanya perbedaan signifikan pada status reseptor hormon diantara kelompok dengan metilasi DNA. ${ }^{32}$ Melalui analisa Southern dari region promoter BRCA1, metilasi ditemukan pada $11 \%$ kasus kanker payudara sporadik dan berhubungan terbalik dengan ekspresi estrogen maupun progesteron reseptor
(Catteaau et al, 1999). ${ }^{31}$ Ketika meneliti frekuensi relatif metilasi pada dua kelompok usia penderita kanker payudara antara etnis Afrika-Amerika dan Eropa-Amerika, Songping dkk mendapatkan bahwa penderita kanker payudara etnis Afrika-Amerika berusia muda (< 50 tahun) dan ER negatif secara signifikan memiliki indeks metilasi lebih tinggi pada lokus $\mathrm{CDH} 13$ dibandingkan dengan penderita kanker payudara etnis Eropa-Amerika dengan karakteristik yang sama. ${ }^{33}$

\section{SIMPULAN}

Kejadian kanker payudara wanita usia muda di RSUP dr. M. Djamil Padang selama 3 tahun (2012-2014) yaitu $27,1 \%$ sedangkan usia tua $72,9 \%$. Terdapat perbedaan karakteristik dan gambaran subtipe molekuler kanker payudara antara penderita kanker payudara wanita usia muda dan tua, dimana penderita kanker payudara usia muda cenderung memiliki ukuran tumor relatif besar, kelenjar getah bening positif, adanya invasi limfovaskuler, grade tumor yang tinggi, indeks proliferasi Ki67 tinggi serta reseptor hormon yang negatif.

Ada kecenderungan perbedaan prognosis kanker payudara wanita antara penderita usia muda dan tua berdasarkan subtipe molekuler namun tidak bermakna secara statistik.

\section{DAFTAR RUJUKAN}

1. Falck AK, Fernö M, Bendahl PO, Rydén L. St Gallen molecular subtypes in primary breast cancer and matched lymph node metastases - aspects on 
distribution and prognosis with luminal $A$ tumours: result from a prospective randomized trial. BMC cancer. 2013; 13: 558: $1-10$

2. De Kruif EM, Bastiannet E, Rubertá F, De Craen AJM, Kuppen PJK, Smit V TBHM, et al. Comparison of frequencies and prognostic effect of molecular subtypes between young and elderly breast cancer patients. Mol Oncol 2014; 8: 1014-1025

3. Cardoso $\mathrm{F}$ et al. The European Society of Breast Cancer Specialists recommenddations for the management of young women with breast cancer. Europ J Cancer 2012; 48: 3355- 3377

4. Goldhirsch A, Winer EP, Coates AS, Gelber RD, Piccart-Gebhart M, Thürlimann $\mathrm{B}$, et al. Personalizing the treatment of women with early breast cancer: highlight of the St Gallen International Expert Consensus on the Primary Therapy of Early Breast Cancer 2013. Ann Oncol 2013; 00: 1-18

5. Lyman $\mathrm{GH}$, Kuderer NM, Lyman SL, Debus M, Minton S, Balducci L, et al. Menopausal status and the impact of early recurrence on breast cancer survival. Cancer Control 1997; 4(4): 335-341

6. Rudat $\mathrm{V}$ et al. Age 40 years or younger is an independent risk factor for locoregional failure inearly breast cancer: a single-institutional analysis in Saudi Arabia. Journal of oncology Hindawi Publishing Corporation. 2012: 1-10

7. Mutlu H, Ozdogan M, Colak T, Akca Z, Buyukcelik A. Variation in prognostic factors and molecular phenotype with menopausal status in Turkish patients with breast cancer. Int $\mathrm{J}$ Hematol Oncol 2013; 2(23): 109-116

8. Livi $L$ et al. The impact of young age on breast cancer outcome. Europ J Surg Oncol 2010; 36: 639-645

9. Clark GM, Osborne CK, McGuire WL. Correlation between estrogen receptor, progesterone receptor, and patient characteristics in human breast cancer. J Clin Oncol 1984; 2(10): 1102-1109

10. Diab SG, Elledge RM, Clark GM. Tumor characteristic and clinical outcome of elderly women with breast cancer. Journal National Cancer Institute. 2000; 92(7): 550-556

11. Meagan $B$, James $F$, Nehmat $H$, Judy $K$, John B: Breast cancer in young women. Australian Family Physician. 2005; 34: 851-855

12. Liukkonen $S$, Leidenius $M$, Saarto $T$, Sjöström-Mattson J. Breast cancer in very young women. Europ J Surg Oncol 2011; 37: 1030-1037

13. Assi HA., Khoury KE, Dbouk H, Khalil LE, Mouhieddine TH, El Saghir NS. Epidemiology and prognosis of breast cancer in young women. $J$ Thoracic Dis 2013; 5(S1): S2-S8

14. Freedman RA, Partridge $\mathrm{AH}$. Management of breast cancer in very young women. The Breast. 2013; 22: S176-S179

15. Kwon JH et al. Triple negativity and young age as prognostic factors in lymph node-negative invasive ductal carcinoma of $1 \mathrm{~cm}$ or less. BMC Cancer. 2010; 10: 557

16. Beadle BM. Ten-year recurrence rates in young women with breast cancer by locoregional treatment approach. Int $\mathrm{J}$ Rad Oncol 2009; 73(3): 734-744

17. Stopeck AT. Breast cancer. Diakses dari:

http://emedicine.medscape.com/article/1 947145-overview\#aw2aab6b2b7.

18. Bradley KT. Prognostic and Predictive Factors in Breast Cancer. Newspath. Diakses dari: http://www.cap.org/ apps/ docs/newspath/0709/prognostic and pr edictive factors in breast cancer.pdf.

19. National Cancer Institute. Cancer staging. Diakses dari: http://www. cancer.gov/cancertopics/factsheet/detec tion/staging. 
20. Weigel MT, Dowsett M. Current and emerging biomarkers in breast cancer: prognosis and prediction. EndocrineRelat Cancer 2010; 17: R245-R262

21. Fasching PA, Heusinger K, Haeberle L, Niklos M, Hein A, Bayer CM, et al. Ki67, chemotherapy response, and prognosis in breast cancer patients receiving neoadjuvant treatment. BioMed Central Cancer 2011; 11 (486): 1-13

22. Pestalozzi BC, Zahrieh D, Mallon E, Gusterson BA, Price KN, Gelber RD, et al. Distinct clinical and prognostic features of infiltrating lobular carcinoma of the breast: combined results of 15 international breast cancer study group clinical trials. J Clin Oncol 2008; 26:3006-3014

23. Reed AEM, Kutasovic JR, Lakhani SR, Simpson PT. Invasive lobular carcinoma of the breast:nmorphology, biomarkers and 'omics. Breast Cancer Research 2015; 17(12):1-11

24. Rakha EA, Reis-Filho JS, Baehner F, Dabbs DJ, Decker T, Eusebi V, et al. Breast cancer prognostic classification in the molecular era: the role of histological grade. Breast Cancer Research 2010, 12: 207

25. Suyatno, Pasaribu ET. Bedah onkologi diagnostik dan terapi. Sagung seto. 2010: 62

26. Timovska YO, Pivnyuk VM, Oliynichenko GP, Anikushko MF, Zachartseva LM, Chekhun VF. Relation between pathomorphological response in tumors after neoadjuvant chemotherapy and clinico-morphological and molecular prognostic factors in patients with breast cancer. Experiment Oncol 2009; 31(4): 231-236
27. Mohammed ZMA, McMillan DC, Edwards J, Mallon E, Doughty JC, Orange $\mathrm{C}$, et al. The relationship between lymphovascular invasion and angiogenesis, hormone receptors, cell proliferation and survival in patients with primary operable invasive ductal breast cancer. BMC Clin Pathol 2013; 13(31): 1-9

28. Song $Y J$, Shin $S H$, Cho JS, Park $M H$, Yoon JH, Jegal YJ. The role of lymphovascular invasion as a prognostic factor in patients with lymph node positive operable invasive breast cancer. J breast Cancer. 2011; 14(3): 198-203

29. Cianfrocca M, Goldstein LJ. Prognostic and predictive factors in early stage breast cancer. The Oncologist. 2004;9:606-616

30. Michaelson JS, Silverstein $M$, Cheongsiatmoy JA, Taghian A, Powell $S$, Hughes $K$, et al. The effect of tumor size and lymph node status on breast carcinoma lethality. Cancer 2003;98(10): 2133-2143

31. Yang $X$, Yan L, Davidson NE. DNA methylation in breast cancer. Endocrinerelat Cancer 2001;8: 115-127

32. Feng W, Shen L, Wen S, Rosen DG, Jelinek $J, H u ~ X$, et al. Correlation between $\mathrm{CpG}$ methylation profiles and hormone receptor status in breast cancers. Breast Cancer Research 2007;9(R57): 1-13

33. Wang $S$, Dorsey $\mathrm{TH}$, Terunuma $A$, Kittles RA, Ambs S, Kwabi-Addo B. Relationship between tumor DNA methylation status and patient characteristics in African-American and European-American Women with breast cancer. Plos One 2012;7: 1-10 